\title{
BALTARUSIAI LIETUVOS VALSTYBĖS TARYBOJE 1918-1920 METAIS
}

\author{
Dr. Tomasz B£aszczak
}

Vytauto Didžiojo universiteto Česlovo Milošo centras Vytautas Magnus University Czesław Miłosz Centre Laisves al. 53-418, LT-44309 Kaunas El.paštas t.blaszczak@pmdf.vdu.lt

\section{Santrauka}

Straipsnyje atskleidžiamas ir analizuojamas baltarusiu dalyvavimas Lietuvos Valstybes Tarybos darbe nuo jos įkūrimo iki veiklos pabaigos 1920 m. pavasari. Analize koncentruojama į baltarusiu atstovu Taryboje veikla nuo $1918 \mathrm{~m}$. rudens. Išsamiai nagrinejjamos baltarusiu atstovu iejjimo $\dot{j}$ Tarybos sudèti aplinkybès, lietuviu ir baltarusiu bendradarbiavimo sąlygos. Atkreipiamas demesys i tolesnius baltarusiu frakcijos Taryboje darbus, pavieniu jos nariu veikla ir politines pažiüras, $j$ baltarusiu ir lietuviu santykiu raida. Taip pat aptariamas baltarusiu atstovu vaidmuo Lietuvos užsienio politikoje ir įtaka tarptautiniams santykiams.

Reikšminiai žodžiai: Lietuvos Taryba; Vilniaus baltarusių rada; baltarusių sekretoriatas; Lietuvos tautinès mažumos.

\section{Ivadas}

Baltarusių ir lietuvių santykiai Lietuvos Valstybės Tarybos (toliau LVT) veikimo laikotarpiu ilgai buvo mažiau tyrinètas tiek Lietuvos, tiek Baltarusijos istorijos epizodas. Tik po Česlovo Laurinavičiaus straipsnių, 
pasirodžiusių XX a. 9 dešimtmetyje, galima kalbèti apie tokios problemos egzistavimą lietuvių istoriografijoje ${ }^{1}$. Šią problematiką vèliau plètojo Šarūnas Liekis ${ }^{2}$ ir Edmundas Gimžauskas ${ }^{3}$. Minèti tyrinètojai baltarusių ir lietuvių santykius analizavo plačiame - tiek Lietuvos valstybės genezès, tiek jos tarptautinių santykių - kontekste. Gilesnę baltarusių ir lietuvių santykių analizę pateikia E. Gimžauskas, tačiau baltarusių dalyvavimas LVT yra analizuojamas tik iki 1918 m. lapkričio mèn., vèliau yra akcentuojama Vyriausybės, Gudų reikalų ministerijos ir Baltarusių Liaudies Respublikos veikla. Labai trūksta Baltarusijos mokslininkų rimtesnių tyrimų šia tema - tai lemia kalbinis apribojimas.

Straipsnio tikslas - išanalizuoti baltarusių dalyvavimą LVT nuo 1918 m. lapkričio 27 d. iki 1920 m. gegužès mèn., kai LVT veikè vadinamoji Baltarusių (Gudų) $)^{4}$ frakcija. Rengiant straipsnị panaudota archyvinè medžiaga, saugoma ịvairiuose Lietuvos ir Baltarusijos archyvuose, remtasi publikuotais šaltiniais bei baltarusių ir lietuvių spauda.

\section{Lietuvos Taryba ir baltarusių klausimas}

Lietuvių ir baltarusių santykius iki $1917 \mathrm{~m}$. vasaros galima apibūdinti kaip draugišką bendradarbiavimą, kuris pasibaigé žlugus buvusios Lie-

${ }^{1}$ Laurinavičius, Č. Dèl Lietuvos buržuazinès Laikinosios vyriausybès politikos Lietuvos teritorijos klausimu 1918-1919 m. Lietuvos TSR mokslu akademijos darbai. Serija A. 1986, Nr. 4, p. 57-69; Laurinavičius, Č. Lietuvos buržuazinès vyriausybès politika valstybès rytinès sienos klausimu. Lietuvos TSR mokslu akademijos darbai. Serija A. 1989, Nr. 1, p. 115-127.

2 Liekis, Š. Rytų Lietuva ir Baltarusija 1915-1923. Lietuvos sienu raida. Vilnius, 1997, t. 2, p. 353-384.

3 Gimžauskas, E. Dèl lietuvių ir gudų politinių siekių išsiskyrimo genezès I pasaulinio karo metais. Lituanistica. 1998, Nr. 4, p. 41-51; Gimžauskas, E. Kai kurios 1918 m. lapkričio $27 \mathrm{~d}$. Lietuvių ir gudų politinio susitarimo aplinkybès (lietuvių ir gudų santykių raida 1917-1918 m.). Lituanistica. 1999, Nr. 4, p. 3-31; Gimžauskas, E. Baltarusiu veiksnys formuojantis Lietuvos valstybei 1915-1923 m. Vilnius: Lietuvos istorijos instituto leidykla, 2003.

4 Šiame tekste sąvokos baltarusiai ir gudai vartojamos lygiagrečiai. 
tuvos Didžiosios Kunigaikštystès atkūrimo planams ${ }^{5}$. Nuo šio momento abiejų tautų atstovai savų tautinio vystymosi kelių ieškojo atskirai, o kai kur pradejo ir konkuruoti, nes tiek lietuviams, tiek baltarusiams tuometinių politinių veiksmų centras buvo Vilnius. Tik 1917 m. pabaigoje baltarusių judejjime išryškejjo Minsko ịtaka, nes ryšiams su vilniečiais trukdè fronto linija, o nuo 1918 m. vasario mèn. - ir vokiečių karinè administracija.

Lietuvos Tarybos (nuo 1918 m. liepos 11 d. - Lietuvos Valstybès Taryba) sukūrimas $1917 \mathrm{~m}$. rudenį sukèlè baltarusių pasipriešinimą. Jau 1917 m. rugsejjo 19 d. Baltarusių tautinis komitetas Vilniuje protestavo prieš istorinès Lietuvos dalijimą, kuris, jų teigimu, ardè vientisą ekonominę erdvę i dvi dalis ir buvo pragaištingas visam regionui ${ }^{6}$. Netrukus baltarusiai nutarè sušaukti savo konferenciją, bet ilgą laiką tokiam sumanymui priešinosi vokiečių administracija.

Lietuvių konferencija Tarybai suteikè teisę kooptuoti ị sudètị naujus narius, ypač tautinių mažumų atstovus. Jų skaičius neturèjo būti didesnis nei ketvirtadalis visos Tarybos sudèties. Mažumų atstovai turèjo „solidarizuotis su priimtuoju Lietuvos nepriklausomybès obalsiu, nebūti susitepę priešinga Lietuvai akcija ir kad suprastų lietuvių kalbą “" . Šiam tikslui buvo sudaryta speciali Tarybos komisija, ì kurią ièjo Steponas Kairys, Aleksandras Stulginskis ir Jonas Vileišis. Kadangi lenkai Tarybos atsiradimą visiškai ignoravo, o žydams atsiskyrimas nuo Rusijos tuo metu buvo nepriimtinas, vienintelè tautinè mažuma, su kuria galima derètis, buvo baltarusiai.

Jau 1917 m. spalio mèn. įvyko pirmieji pasitarimai su baltarusiais.

5 Išsamiau: Gimžauskas, E. Dèl lietuvių ir gudų politinių siekių... Lituanistica. 1998, Nr. 4, p. 41-51.

6 Baltarusiai turejjo omenyje faktą, kad i LVT buvo išrinkti vien atstovai iš okupacinès srities „Lietuva“. Рудовіч, С. Час выбару: праблема самавызначэння Беларусі у 1917 годзе. Мінск: Тэхнологія, 2000, p. 117.

71917 m. rugsèjo 18-22 d. Lietuvių konferencijos posėdžių protokolai. Lietuvos Valstybès Tarybos protokolai, 1917-1918. Sudarè A. Eidintas, R. Lopata. Vilnius: Mokslas, 1991, p. 76-77 (toliau-LVT protokolai). 
Tiesa, ne su visą baltarusių judejjimą apimančia grupe, o su vadinamąja Vaclovo Lastauskio grupuote, kuri išsiskyrè Baltarusių tautiniame komitete $^{8}$. Derybos greit sustojo, nes baltarusiai pateikè sąlygas, pagal kurias kuriama valstybė turètų būti išplèsta baltarusių etninès žemès rytuose ir būtų sudaryta iš dviejų lygiagrečių vienetų, išskirtų kalbiniu principu. Vienintelis konstruktyvus derybų rezultatas - nutarimas tęsti derybas, kai bus sušaukta baltarusių konferencija. Tai atitiko Lietuvių konferencijos nutarimus, skelbiančius, kad mažumos turètų siųsti delegatus i Tarybą per sušauktas konferencijas9.

Reaguodami ì Lietuvos Tarybos formavimą ir jos veiklą baltarusiai 1918 m. sausio 25-28 dienomis surengè konferenciją, kurioje ketino sudaryti baltarusių tautinès atstovybès Oberoste organizacinius pamatus. Tam reikejjo nustatyti santykius su LVT ir jos planais atkurti valstybingumą. Konferencijos dalyviai prièmė rezoliuciją, kurioje teigé, kad „nepripažįsta Lietuvos Tarybos nutarimų kaip Lietuvos ir Baltarusijos balso ir neprisiima atsakomybès už jos politinius įsipareigojimus ${ }^{\text {"10 }}$. Konferencijoje išrinkta Vilniaus baltarusių rada (toliau - VBR), o jos pirmininku paskirtas Antanas Luckevičius. Rada turejjo koordinuoti baltarusiškų organizacijų veiklą ir veikti kaip visų baltarusių atstovybė vokiečių okupuotoje teritorijoje ${ }^{11}$. Igyvendinti antrą tikslą buvo problemiška, nes konferencijoje dalyvavo atstovai tik iš Lietuvos srities, tad i VBR buvo išrinkti išimtinai vilniečiai, dèl to jos ịtaka kitose teritorijose buvo ribota. Konferencijoje vèl pasisakyta už bendros baltarusių ir lietuvių valstybès formavimą ${ }^{12}$.

VBR atstovai atidžiai stebejjo situaciją Minske, kur $1917 \mathrm{~m}$. gruodžio

8 Gimžauskas, E. Kai kurios 1918 m. lapkričio 27 d. Lietuvių ir gudų politinio susitarimo aplinkybės (lietuvių ir gudų santykių raida 1917-1918 m.). Lituanistica. 1999, Nr. 4, p. 5.

9 Ten pat.

${ }^{10}$ Uchwała Zjazdu Białoruskiego. Litwa podczas wojny: zbiór dokumentów, uchwał, odezw i t. p. Zebrał i do druku przygotował. L. Abramowicz. Warszawa: Wydawnictwo Departamentu Spraw Politycznych, 1918, p. 130.

11 Homan. 1918, Nr. 11, p. 2.

12 Gimžauskas, E. Kai kurios 1918 m. lapkričio 27 d. Lietuvių ir gudų... Lituanistica. 1999, Nr. 4, p. 7. 
mèn. įvyko baltarusių suvažiavimas, o toliau veikè rada, kuri paskelbė Baltarusijos Liaudies Respublikos (toliau - BLR) ịkūrimą. Tiesa, reikia manyti, kad būtent VBR atstovai, kuriems vokiečiai leido išvykti ị Minską, greičiausiai jkvejpti Lietuvos nepriklausomybès paskelbimo vasario $16 \mathrm{~d}$., turejo lemiamos ittakos BLR nepriklausomybès paskelbimui $1918 \mathrm{~m}$. kovo $25 \mathrm{~d}$.

Nors santykiai tarp VBR ir Tarybos buvo riboti, $1918 \mathrm{~m}$. balandžio 23 d. surengtos bendros derybos su Tarybos mažumų komisija. Susitikime dalyvavę VBR atstovai Antanas Luckevičius, Daminikas Siamaška ir Janka Stankevičius pirmą kartą pripažino Lietuvos nepriklausomybę, bet iškèlè abejonių dèl jos teritorijos ${ }^{13}$. Delegacija taip pat deklaravo, kad baltarusių tikslas yra LDK atgimimas, kaip Lietuvos ir Baltarusijos federacija, o Tarybos kuriama valstybė yra tik mažoji Lietuva, galinti tapti LDK atgimimo branduoliu. Baltarusiai išreiškè norą prisijungti prie Tarybos darbų, bet reikalavo, kad Lietuvos Taryba būtų performuota į Lietuvos Valstybès Tarybą, kurioje baltarusiai turètų savo proporcingą atstovybę; žemės ị Vakarus nuo Brastos taikos linijos neturètų būti dalijamos (t. y. Lietuvai turètų priklausyti Balstogés ir Bielsko apskritys); būsimąją valstybę sudarytų du federaciniai vienetai. Lietuviai pritarè pasiūlymui dèl Bielsko ir Balstogès, bet kategoriškai atsisakè federacijos su Minsku, nes LVT neturejjo Lietuvių konferencijos suteiktų igaliojimų spręsti tokius klausimus ${ }^{14}$. Lietuviai dar tą pačią dieną pasiūlè dviem baltarusių atstovams ịeiti ị Tarybą, bet baltarusiai reikalavo proporcingos atstovybės. Mažumų komisija, pateikusi raportą apie savo veiklą, balandžio $27 \mathrm{~d}$. buvo likviduota, o mažumų reikalai palikti Tarybos prezidiumo kompetencijai ${ }^{15}$. Reikia pažymėti, kad teritorinis klausimas, itin svarbus baltarusiams, Taryboje taip ir nebuvo oficialiai suformuotas iki $1918 \mathrm{~m}$. vidurio, jis pamažu èmè atsirasti tik derybose su vokiečiais $1918 \mathrm{~m}$. antroje pusèje.

131918 m. balandžio 24 d. Lietuvos Tarybos ir VBR pasitarimo protokolas. Lietuvos centrinis valstybés archyvas. F. 1014, ap. 1, b. 24, lap. 1 (toliau-LCVA).

141918 m. gegužès 31 d. Lietuvos Tarybos prezidiumo pareiškimas Gudų Tarybai Vilniuje. LCVA. F. 923, ap. 1, b. 1392, lap. 3.

$151918 \mathrm{~m}$. balandžio $27 \mathrm{~d}$. Lietuvos Tarybos posėdžio protokolas Nr. 74. LVT protokolai. P. 243-244. 


\section{Baltarusių atstovų ièjimas $i$ Lietuvos Valstybès Tarybą}

Prie tautinių mažumų reikalų buvo grižzta tik 1918 m. rudenį, kai vokiečių valdžia nutarẻ leisti lietuviams kurti vyriausybę ir laipsniškai perduoti jiems valdžią su sąlyga, kad LVT sudètị papildys visų tautinių mažumų atstovai. Spalio 30 d. buvo sukurta nauja komisija, kurią sudarè Jurgis Alekna, Kazys Bizauskas ir J. Vileišis, tačiau konkrečių derybų buvo nuspręsta palaukti, kol bus sudaryta Vyriausybè. Būtent Vyriausybė vedè tolesnes derybas su baltarusiais, tiesa, dèl šaltinių trūkumo nèra galimybės atkurti visą derybų raidą ir, kas svarbiausia, kokie buvo tų derybų nutarimai. Yra žinomi rezultatai: baltarusių atstovai ièjo į LVT, buvo sukurta Gudų ministerija, Lietuvos kariuomeneje suformuoti baltarusių daliniai. Vis dèlto šių nutarimų sąlygos yra gana miglotos. Abi pusès nesudarè nè vieno bendro dokumento, greičiausiai neįvyko nė vienas bendras posèdis, o visas derybas vainikavo kelių dokumentų mainai. Vien deklaracijomis paremtas susitarimas sukūrè struktūras, kurios, kaip parodè laikas, pagal abiejų pusių sumanymą turèjo funkcionuoti kitaip ${ }^{16}$.

Derybos vyko baltarusiams gana sudètingu metu. VBR pirmininkas A. Luckevičius tuomet dirbo Minske, buvo diplomatinès misijos Kijeve narys, o lapkričio 22 d. tapo BLR Ministru Pirmininku ir užsienio reikalų ministru, todèl neturèjo jokios ịtakos ịvykiams Vilniu$\mathrm{je}^{17}$. Lapkričio $3 \mathrm{~d}$. VBR išleido rezoliuciją, kurioje paskelbẻ save kaip

${ }^{16}$ I gana keistą lietuvių ir baltarusių susitarimo būdą pirmasis dèmesị atkreipe E. Gimžauskas. Išsamiau apie derybų raidą: Gimžauskas, E. Kai kurios 1918 m. lapkričio 27 d. Lietuvių ir gudų... Lituanistica. 1999, Nr. 4, p. 22.

${ }^{17}$ Anksčiau, pirmiausia baltarusių istoriografijoje, dominavo požiūris, kad pagrindinis LVT ir VBR susitarimų iniciatorius buvo būtent A. Luckevičius, bet šis teiginys visiškai atmetamas, juo labiau kad baltarusių ịtraukimas į Lietuvos valstybès kūrimo darbus tuo metu aktualesnis buvo Lietuvai. Kita vertus, kadangi derybos su vokiečiais, bolševikais ir ukrainiečiais nedavè jokių rezultatų, o raudonoji armija artejo prie Minsko, baltarusiams derybos su lietuviais ir kuriama Lietuvos valstybe buvo praktiškai vienintelè galimybè išlaikyti kokią nors poziciją tarptautinèje erdvèje ir daryti ịtaką tolesnei klausimo dèl baltarusių raidai. 
lygiateisę su LVT krašto baltarusių atstovybe ir išreiškė norą sušaukti bendrą lietuvių ir baltarusių parlamentą ${ }^{18}$. Taip pat VBR pristatė sąlygas, kurias išpildžius būtų pasiruošusi pasiųsti savo atstovus ị LVT: teritorinis Bielsko ir Balstogés klausimas, proporcinga baltarusių atstovybe parlamente ir vyriausybeje, baltarusiškų žemių autonomija ir baltarusių kariuomenės ịkūrimas. Nors ị VBR pareiškimą nebuvo atsakyta, šie reikalavimai tapo išeities tašku tolesnèms deryboms.

VBR savo reikalavimus pakartojo ir išplètė dar porą kartų - lapkričio 14 ir 21 d.: baltarusių atstovai turejjo sudaryti 25 proc. LVT narių; jie turèjo gauti vieną ministeriją, turèjo būti sukurtas baltarusių sekretoriatas (iš LVT narių) kaip organas, tarpininkaujantis tarp Vyriausybės ir baltarusių gyventojų; baltarusių gyvenama teritorija turejjo būti aprūpinta lěšomis, proporcingomis jos plotui ir populiacijai; Lietuvos ribose turejo pasilikti Balstogè su Bielsku; baltarusiškoms dalims turèjo būti suteikta autonomija su baltarusių oficialia kalba; nedelsiant turèjo būti sukurta baltarusiška mokyklų inspekcija. Gavusi Vyriausybės pritarimą šioms sąlygoms, VBR buvo pasiruošusi iš karto išsiųsti savo atstovus į LVT.

Vyriausybe iš pradžių neprièmė konkrečių sprendimų, tik nutarè, kad bendradarbiavimas yra svarbus. Lapkričio $23 \mathrm{~d}$. Vyriausybė nusprendè, kad besąlygiškai sutinka tik dèl atskiros mokyklų inspekcijos sudarymo bei pritarẻ Baltarusių sekretoriato kūrimui. Nuo atsakymo ị kitus klausimus susilaikè: Bielsko ir Balstogès klausimas liko taikos kongreso užduotimi (ị delegaciją kongresui turèjo įeiti ir baltarusių atstovai), klausimus dèl autonomijos ir baltarusių kalbos turejo spręsti Steigiamasis Seimas.

Nors jokių konkrečių nutarimų Vyriausybès ir VBR derybose nebuvo pasiekta, klausimas dèl gudų atstovybès iš karto ịtrauktas ị LVT posèdžio lapkričio 27 d. darbotvarkę. Derybų su baltarusiais rezulta-

${ }^{18}$ Homan. 1918, Nr. 88, p. 2. 
tus paskelbė premjeras Augustinas Voldemaras ${ }^{19}$. Jo nuomone, baltarusiai neaiškiai formavo savo reikalavimus, todèl derybos tiek ilgai užsitęsè. Ne visai suprantama buvo Baltarusių sekretoriato koncepcija, bet pagaliau paaiškejjo, kad jo „uždavinys susisiekti su visomis ministerijomis ir vienyti gudų reikalus“.

Po A. Voldemaro pareiškimo Antanas Smetona perskaitė LVT prezidiumo rezoliuciją, kuri buvo priimta vienbalsiai: „Pareiškus gudų Radai, kad ji stovi ant Lietuvos valstybès nepriklausomybès pamato ir nori dirbti bendrai su Lietuvos valdžia Lietuvos valstybès atstatymui, Valstybės Taryba, nerišdama klausimo dèl procentinių tautų santykių Lietuvoje, kooptuoja šešius gudų atstovus, remdamasi pertraktacijomis Gudų Rados ir Ministeriu Pirmininku ir pačios Rados pareiškimu Ministerių Pirmininkui, jog šešių gudų atstovybė yra nuo visų Lietuvos gudų gyventojų “20.

Toliau A. Smetona pristatė baltarusių atstovų pavardes, kurias VBR išrinko jau lapkričio $24 \mathrm{~d} .^{21}$ : Kazimieras Falkevičius ${ }^{22}$, Ivanas Luckevičius ${ }^{23}$,

${ }_{19}$ A. Voldemaras mané, kad i LVT taip pat kreipèsi Gardino krašto atstovai. Tiesa, LVT klausimas dèl buvusios Gardino gubernijos nuo $1918 \mathrm{~m}$. žiemos tapo labai svarbus. Žinodama, kad VBR neturi jokios ịtakos Gardino krašte, Vyriausybe rado ten partnerị - Gardino krašto gudų valdybą (rus. Uprava), kurią išrinko gruodžio 1-2 dienomis vykęs Gardino gubernijos suvažiavimas. Bendrame lietuvių ir baltarusių santykių kontekste tai buvo labai svarbus epizodas, bet jis labiau susijęs su Vyriausybès politika, o ne LVT reikalais.

${ }^{20}$ Tuo metu LVT buvo 18 narių, tad 6 baltarusių kooptavimas atitiko 25 proc. postulatą. 1918 m. lapkričio 27 d. LVT posėdžio protokolas Nr. 114. LVT protokolai. P. 402.

${ }^{21}$ Pagal D. Siamašką kandidatais ị LVT dar buvo A. Levickis ir V. SviatopolkasMirskis. LCVA. F. 383, ap. 7, b. 56, lap. 19; 1918 m. lapkričio 24 d. Visuotinio VBR posèdžio protokolas. Baltarusijos valstybinis literatūros ir meno archyvas-muziejus F. 3, ap. 1, b. 140, lap. 33. (toliau-BVLMA-M).

${ }^{22}$ Kazimieras Falkevičius (brus. Казімір Фалькевіч) (1865-1922) gimè ir gyveno Šeštokuose (Turgelių valsčius), valstietis, aktyvus baltarusių nacionalinis veikejjas.

${ }^{23}$ Ivanas Luckevičius (brus. Іван Луцкевіч) (1881-1919) gimė Šiauliuose, mokèsi Liepojoje ir Minske, $1902 \mathrm{~m}$. baige Maskvos archeologinị institutą, $1905 \mathrm{~m}$. - teisę Peterburgo universitete. Vienas iš baltarusių judejjimo Peterburge pradininkų, pirmosios baltarusių politinès partijos Baltarusių revoliucinès (socialistinès) hromados ịkūrejjas, baltarusių spaudos Vilniuje iniciatorius ir bendradarbis, baltarusių gimnazijos Vilniuje ¡̣kūrèjas. Mirè nuo džiovos Zakopanėje (1991 m. palaikai buvo perkelti ị Rasų kapines). Jo archeologinè ir kraštotyros kolekcija tapo Baltarusių muziejaus Vilniuje pradžia. 


\section{Lastauskis ${ }^{24}$, kun. Vladzislavas Taločka ${ }^{25}$, Daminikas Siamaška ${ }^{26}$ ir} Janka Stankevičius ${ }^{27}$. LVT baltarusių kandidatus prièmè atviru balsavimu: 15 balsavo „už“, 2 susilaikè (Donatas Malinauskas ir J. Vileišis) ir 1 - „prieš‘ ${ }^{\text {“28. }}$ Mykolas Biržiška, kuris balsavo „priešc, argumentavo, kad

${ }^{24}$ Vaclovas Lastauskis (brus. Вацлаў Ластоўскі) (1883-1938) gimė Kalesninkuose (Dysnos valsčius), savamokslis. Nuo 1903 m. dirbo Peterburge, kur vedè Mariją Ivanauskaitę, nuo 1906 m. gyveno Rygoje. Baltarusių socialistinès hromados narys, 1909-1915 m. - laikraščio „Naša niva“ sekretorius, pirmosios Baltarusijos istorijos baltarusių kalba autorius (1910). Pirmojo pasaulinio karo metu aktyvus politinis ir visuomeninis veikèjas, 1919 m. gruodžio mèn. - $1923 \mathrm{~m}$. - Baltarusių Liaudies Respublikos Ministras Pirmininkas. Nuo 1920 m. lapkričio mèn. gyveno Kaune, 1923-1927 m. - Užsienio reikalų ministerijos darbuotojas, žurnalo „Kryvič““ leidejjas. 1927 m. išvyko ị Minską, kur dirbo Valstybės muziejaus direktoriumi, Mokslų akademijos sekretoriumi. 1930 m. ištremtas ị Saratovą, 1937 m. vèl areštuotas, nuteistas mirties bausme.

25 Vladzislavas Taločka (brus. Уладзіслаў Талочка) (1887-1942) gimė Gardine, 1909 m. baigè Vilniaus dvasinę seminariją, 1910-1914 m. studijavo teologiją ir filosofiją Insbruko katalikų universitete. Po studijų grįžo ị Vilnių, kunigavo Šv. Stepono ir buvusioje Bernardinų bažnyčiose, nuo to laiko bendradarbiavo su baltarusiška, lietuviška ir lenkiška Lietuvos spauda. 1918 m. tapo LVT nariu, bet bolševikams užèmus Vilnių, ten ir liko, dirbo savo parapijoje, tęsè publicistinị darbą iki 1938 m., kada buvo lenkų administracijos ištremtas, grịžo tik po miesto perdavimo Lietuvai, čia ir mirè. Palaidotas Rasų kapinèse.

26 Daminikas Siamaška (brus. Дамінік Сямашка) (1878-1932 m.) gimė Surgeliuose (pagal kitus duomenis - Vilniuje), ugniagesys. I baltarusių judèjimą Vilniuje įsitraukè per $1905 \mathrm{~m}$. revoliuciją. Pirmojo pasaulinio karo metu - Vilniaus gaisrininkų komendantas, aktyvus masonų ložès ir baltarusių organizacijų veikèjas. Lietuvos delegacijos Paryžiaus konferencijai narys, 1920-1923 m. - ministras baltarusių reikalams. Vèliau dirbo ugniagesybos srityje, ịvairių žurnalų redaktorius.

27 Janka Stankevičius (brus. Ян Станкевіч) (1891-1976 m.) gimė Arlianiatų kaime, Ašmenos apskrityje. Pirmojo pasaulinio karo metu tarnavo Rusijos armijoje, per revoliuciją ịsitraukè ị baltarusių judèjimą. Vilniaus baltarusių gimnazijos absolventas (1921), 1926 m. baigè Karolio universitetą Prahoje, slavų filologijos ir istorijos daktaras. Grịžęs ị Lenkiją dirbo baltarusių kalbos dėstytoju Varšuvos (1928-1932) ir Vilniaus Stepono Batoro (1927-1940) universitetuose. 1928-1930 m. - Lenkijos Seimo narys. Per Antrajj pasaulinị karą iš pradžių atsidūrė Varšuvoje, po to vokiečių okupuotajame Minske, kur buvo aktyvus baltarusių organizacijų veikejjas. 1944 m. pasitraukè ị Vakarus, nuo 1949 m. gyveno JAV, ịsitraukè ị emigracijos visuomeninị darbą, daug publikavo ịvairiuose baltarusiškuose leidiniuose.

${ }^{28}$ LVT protokolai. P. 403. 
,jis negalįs balsuoti už kooptavimą visų atstovų, nes jų tarpe yra žmonių, prieš kuriuos jis visuomet balsuos ${ }^{\text {“29. }}$.

Po pertraukos D. Siamaška ir V. Lastauskis gudų atstovybès vardu pasirašė deklaraciją. Ją perskaitė V. Lastauskis: „Gudų Rada, išrinkta sausio 25-27 d. 1918 m. konferencijos atstovų tų gudų žemių, kurios yra ị vakarus nuo senojo fronto, remdamasi minètos konferencijos nusprendimais ir laikydama idealu Lietuvių-Gudų federacinès sudarymą dèl svarbumo gyvenamojo momento, rado reikalingu prisidèti prie konkretaus Valstybès Tarybos darbo, laikydama ją vienatine dabar sekama Lietuvos atstovybe. Gudų Rada tiki, kad dvi tautos sujungtos istorijos praeitimi ir ekonominemis sąlygomis padavusios viena kitai rankas, ịstengs laimèti sau laisvą ir nepriklausomą gyvenimą, eidamos keliu demokratingo bendros valstybès statymo ${ }^{\text {“30. }}$.

V. Lastauskis taip pat deklaravo, kad ,gudų atstovybė nutarè sutartinai dirbti su Valstybės Taryba, neatsižvelgiant ị kitas tautas. Bendra praeitis ir dabartinis vargas rodo kelią mūsų bendram darbui“. Tą pačią dieną VBR pristatė Juozapo Voronko kandidatūrą i gudų reikalų ministrus, bet jo paskyrimas, kaip ir ministerijos formavimas, užsitęsė dar beveik porą savaičių. Baltarusių ịejimas ị LVT vienareikšmiškai buvo lietuvių laimèjimas.

Baltarusių institucijų veikla Lietuvos valstybejje niekada nebuvo paremta oficialiu jų kompetencijų apibrèžimu. Kadangi didesnių problemų dèl baltarusių karinių dalinių nebuvo, tiek ministerijos, tiek sekretoriato funkcionavimas visiškai nebuvo reguliuojamas. Bandymai nustatyti tam tikras teisines ribas ilgą laiką buvo siūlomi iš baltarusių pusès. Jų nuomone, lietuviai 1918 m. lapkričio mẻn. pripažino baltarusiškų žemių

${ }^{29}$ Savo atsiminimuose M. Biržiška teigè, kad omenyje turejjo I. Luckevičių ir D. Siamašką. Kartu jis pabrěžè, kad vertinant D. Siamaškos veiklą iš vėlesnių ìvykių perspektyvos jo abejonès buvo visiškai pateisinamos. LVT protokolai. P. 403; Biržiška, M. Dèl mūsu sostinès (iš Vilniaus darbo atsiminimu): ligi $1919 \mathrm{~m}$. liepos 1 d. London: Nida, 1960, t. 1, p. 38.

${ }^{30}$ LVT protokolai. P. 404; Засецкі, М. Міністэрства беларускіх: спраў за 10 месяцау істнаваньня, 1.XII.1918 - 1.X.1919: Кароткі нарыс. Коўна, 1919, р. 2. 
autonomiją. Kadangi visos susitarimų aplinkybès nèra žinomos, sunku vienareikšmiškai spręsti, ar baltarusiams buvo pažadèta kokia nors autonomijos forma ${ }^{31}$. Nors oficialiai lietuviai neigè autonomijos pripažinimą, kai kurie jų veiksmai (pvz., baltarusių ministerijos perkèlimas ị Gardiną, o ne ị Kauną, kaip visos Vyriausybės) galèjo pretenduoti ị tokios autonomijos užuominas.

\section{Baltarusių veikla Lietuvos Valstybės Taryboje}

Baltarusių sekretoriatas (kurị sudarè visi baltarusių atstovai LVT), sukurtas pagal $1918 \mathrm{~m}$. lapkričio mèn. nutarimą, niekada netapo formalizuota institucija. Lietuviai šią grupę traktavo kaip "gudų frakciją“, panašiai kaip kitas politinių partijų grupes. Išskyrus pradinị sekretoriato veiklos laikotarpi Vilniuje 1918 m. lapkričio ir gruodžio mėn., sunku atrasti jo ar netgi pavienių asmenų veiklos pėdsakų. Priežastys yra ne tik šaltinių trūkumas, bet ir specifinis baltarusių pozicijų vertinimas Lietuvos valstybeje.

Viena iš pirmųjų užduočių, kurią turèjo atlikti sekretoriatas kartu su gudų reikalų ministru - teikti kandidatūras į Vyriausybės komisarus baltarusių gyvenamose apskrityse ${ }^{32}$. Pirmiausia baltarusių atstovai dirbo einamuosius LVT darbus. Sunku pasakyti, kokia situacija buvo atskirų komisijų posėdžiuose, bet LVT plenume kartais iškildavo problema dèl kalbos, nes nè vienas baltarusių atstovas nemokejjo lietuvių kalbos. 1918 m. gruodžio 2 d. LVT protokole liko J. Stankevičiaus balso įrašas,

${ }^{31}$ Kaip vèliau teigè A. Smetona: „Laikinoji valdžia èjo iš realių ano laiko sąlygų ir todèl sudarè gudų ministeriją, manydama ịsitvirtinti Vilniuje. Jei būtų pavykę tenai palikti ir įsitvirtinti, tai tikrai būtų plètojusi gudų klausimą toliau; gal būtų prièjusi prie teritorialinès gudų autonomijos.“ A. Sm. [A. Smetona]. Be rytojaus. Vairas. 1924, Nr. 6, p. 2.

321918 m. pabaigoje Vyriausybès administracija Pietų Lietuvoje (buv. Gardino gubernijos teritorijoje) buvo kuriama pagal baltarusių rekomendacijas. Vis dèlto komisarai turèjo menką įtaką sprendžiant vietinius reikalus, nes jų nepripažino tiek vokiečių okupacinè valdžia, tiek lenkų valdžios atstovai, o svarbiausia - vietos gyventojai. 
diskusijoje apie gen. Kiprijoną Kondratovičių jis nurodo, kad „gudai nesupranta to, kas dabar kalbama taip svarbiu klausimu“"33.

Lapkričio 29 d. ị LVT komisiją Vilniaus universiteto statuto projektui parengti buvo išrinktas V. Lastauskis ${ }^{34}$, kuris tame posėdyje pabrèžè būtinybę ịtraukti baltarusių kalbą i universiteto studijas: „Lietuvių praeitis taip surišta su baltgudžių kalba. Pažinimui mūsų krašto istorijos yra labai svarbios „Lietuvos Metrikos“, tuo tarpu jos parašytos gudų kalba“. V. Lastauskiui buvo pritarta, o M. Biržiška pridūrè, kad „Gudų literatūros katedra būtinai reikalinga ir mūsų literatūrai nušviesti, ir pilietiškumo žvilgsniu“"35. Pagaliau katedra, kuri turèjo veikti Socialinių mokslų fakultete, buvo pavadinta Gudų kalbos, istorijos ir literatūros katedra ${ }^{36}$. V. Lastauskio ir I. Luckevičiaus iniciatyva statute atsirado įrašas, kad „be lietuvių kalbos, lekcijos, prireikus, skaitomos ir kitomis kalbomis ${ }^{\text {“37. }}$. $1918 \mathrm{~m}$. gruodžio $5 \mathrm{~d}$. priimtas statutas liko tik popieriuje, nors vèliau tapo pagrindu $1922 \mathrm{~m}$. Kaune atsidariusiam Lietuvos universitetui. Vis dèlto pasikeitus geopolitinei situacijai, baltarusių kalbos katedra tapo nebeaktuali ${ }^{38}$.

Kadangi nebuvo galimybių surengti rinkimus ị Steigiamąji Seimą, vienu iš svarbiausių LVT uždavinių 1918 m. gruodžio mèn. buvo konferencijos, kuri įteisintų LVT kaip legalią visų Lietuvos gyventojų atstovybę, organizavimas. Keltas klausimas, ar reikia perrinkti naują Tarybą, ar užtektų tik papildyti esamos LVT sudètį. Atrodo, baltarusių atstovybė šiuo klausimu bendros nuomonès neturèjo. V. Laustausko teigimu, atsižvelgiant ị tuometinę situaciją, LVT sudètị reikèjo tik papildyti, nes visos

331918 m. gruodžio 2 d. LVT posėdžio protokolas Nr. 118. LVT protokolai. P. 429.

341918 m. lapkričio 29 d. LVT posėdžio protokolas Nr. 116. LVT protokolai. P. 419.

35 Ten pat, p. 416.

36 Vilniaus universiteto statutas (Valstybès Tarybos priimtas $1918 \mathrm{~m}$. gruodžio mèn. 5 d.). Lietuvos valstybès teisès aktai (1918 II 16-1940 VI 15). Vilnius: Teisès institutas, 1996, p. 341.

371918 m. gruodžio 5 d. LVT posėdžio protokolas Nr. 120. LVT protokolai. P. 439.

38 Vienintelis baltarusiškas dalykas universiteto didaktinèje pasiūloje buvo baltarusių literatūros istorijos paskaitos, kurias nuo 1927 m. skaitė M. Biržiška. 
Tarybos perrinkimas galëjo turèti neigiamų pasekmių. Jis siūlè „vesti pririnkimus ị Tarybą tautinėmis kurijomis“39. Savo ruožtu I. Luckevičius, kuris buvo išrinktas ị LVT komisiją konferencijai paruošti, siūlè suteikti konferencijai kuo „plačiausius iggaliojimus, kad negalima būtų padaryti jokių užmetimų“40.

Gana greitai pasireiškè pirmieji nesusipratimai tarp Baltarusių sekretoriato ir LVT bei A. Voldemaro Vyriausybès. Jų priežastis buvo naujojo Vilniaus vyskupo Jurgio Matulaičio ingresas. Dar per lapkričio mèn. vykusias derybas VBR išreiške pageidavimą, kad naujasis vyskupas per ingresą pasakytų kalbą baltarusiškai. Šis pasiūlymas buvo priimtas ir ittrauktas ị oficialų A. Voldemaro laišką, taip pat jame nominato buvo paprašyta lietuvių ir baltarusių kalbomis perskaityti probulla ${ }^{41}$. J. Matulaitis pasiūlymą prièmė, bet pabrèžė, kad visų pirma savo kalbą perskaitys lenkiškai. Pagalbos parengti kalbą baltarusiškai J. Matulaitis paprašė kunigo V. Taločkos. Nežinoma, ar nominato kalba buvo parašyta, nes leidimo baltarusiškai sakyti kalbą per ingresą Vilniaus kapitula, kaip šeimininkè, $n^{n e d a v e} \dot{e}^{42}$. Todèl per gruodžio $8 \mathrm{~d}$. vykusị ingresą J. Matulaitis kalbejjo tik lenkiškai ir lietuviškai. Iškilmèse LVT ir Lietuvos Vyriausybės atstovai nedalyvavo, nes kapitula juos boikotavo ir neparuošė atskirų vietų Katedroje.

Baltarusių sekretoriatas dèl susidariusios padèties kaltino LVT ir reikalavo iš jos ryžtingos intervencijos ${ }^{43}$. LVT nariai dvasininkai aiškino, kad tai yra vidiniai Bažnyčios reikalai, ị kuriuos valstybė neturètų kištis.

391918 m. gruodžio 6 d. LVT posėdžio protokolas Nr. 121. LVT protokolai. P. 446-447.

40 Ten pat, p. 443.

${ }^{41}$ Górski, T. Błogosławiony Jerzy Matulewicz. Warszawa: Wydawnictwo Księży Marianów, 2005, p. 153-156; 1918 m. spalio 20 d. Ministrų Tarybos posėdžių protokolas Nr. 4. LCVA. F. 923, ap. 1, b. 9, lap. 5.

42 Ponarski, Z. Władysław Tołłoczko - ostatni obywatel Wielkiego Księstwa Litewskiego. Białoruskie Zeszyty Historyczne. 1997, z. 8, p. 82-84; Górski, T. Błogosławiony Jerzy Matulewicz. Warszawa: Wydawnictwo Księży Marianów, 2005, p. 153, 291.

431918 m. gruodžio 9 d. LVT posėdžio protokolas Nr. 123. LVT protokolai. P. 454; Homan. 1918, Nr. 98, p. 2. 
Dauguma LVT narių buvo kitos nuomonès, tad privertė A. Voldemarą asmeniškai susitikti su vyskupu J. Matulaičiu, kuris pareiškè, kad Vyriausybės raštas buvo sustabdytas kapituloje ir jis pats susipažino su jo turiniu tik po ingreso ${ }^{44}$.

Baltarusių sekretoriatas buvo vienas iš iniciatorių, reikalavusių žydų atstovybę padidinti nuo $2 \mathrm{iki} 3$ atstovų ${ }^{45}$. Tai buvo paskutinis sekretoriato veiksmas, kuriame dalyvavo visi jo nariai. Gruodžio $11 \mathrm{~d}$. posėdis buvo paskutinis prieš suplanuotą pertrauką, o kita LVT sesija prasidejo tik 1919 m. sausio 23 d. Kaune, pasibaigus Antrajai Valstybès konferencijai, kurioje baltarusiams atstovavo tik V. Lastauskis ${ }^{46}$. Anksčiau, gruodžio 21 d., I. Luckevičius ir J. Stankevičius pareiškè, kad „ryšium su paskutiniais vyriausybès ir LVT prezidiumo veiksmais, kurie buvo padaryti be baltarusių atstovų žinių, jie negali toliau laikytis Tarybos nariais “" ${ }^{\text {" }}$. Tikètina, kad „paskutiniu veiksmu“ I. Luckevičius ir J. Stankevičius laikè LVT sprendimą pasitraukti iš Vilniaus ir baltarusiškas institucijas atskirti nuo kitų valstybès valdžios organų, prie kurių pasiliko tik Baltarusių sekretoriatas.

Paskutinèmis $1918 \mathrm{~m}$. dienomis prasidejjus evakuacijai iš Vilniaus, sekretoriato veikla praktiškai buvo sustabdyta. Kunigas V. Taločka ir K. Falkevičius, likę Vilnijoje, nors ir buvo formaliai laikomi LVT nariais, jos posėdžiuose daugiau nebedalyvavo. V. Lastauskis tapo baltarusių atstovu prie Lietuvos pasiuntinybės Berlyne, o D. Siamaška - Lietuvos

441918 m. gruodžio 10 d. LVT posėdžio protokolas Nr. 124. LVT protokolai. P. 456. 451918 m. gruodžio 11 d. LVT posėdžio protokolas Nr. 125. LVT protokolai. P. 458. 46 „Gudų atstovas labai gražiais, jausmingais žodžiais, visai neminėdamas Tarybos, išreiškè vyriausybei savo pasitikèjimą, už ką buvo palydètas gausiais delnų plojimais“"(Lietuva. 1919, Nr. 9, p. 1). A. Luckevičiaus dienoraštyje 1919 m. sausio 21 d. yra priminimas, kad Bielsko komisaras Majevskis, atvykęs iš Kauno ị Gardiną, teigè, kad konferencijoje dalyvavo 7 baltarusiai (Луцкевіч, А. Дзённік. Барацььба за вызваленне. Вільня: Інстытут беларусістыкі, 2009, p. 503). Šios informacijos nepatvirtina kiti šaltiniai.

${ }^{47}$ Pirminiame pareiškimo tekste dar buvo parašyta ,ir be gudų reikalų ministro žinių“, tačiau vėliau išbraukta. Žr. 1918 m. gruodžio 21 d. I. Luckevičiaus ir J. Stankevičiaus raštas LVT. BVLMA-M. F. 3, ap. 1, b. 260, lap. 12; Homan. 1918, Nr. 101, p. 3. 
delegacijos ị Paryžiaus taikos konferenciją nariu ${ }^{48}$. LVT likimas buvo sprendžiamas Antrojoje Valstybès konferencijoje, kurioje nuspręsta papildyti LVT naujais nariais. Atsižvelgta ị V. Lastauskio siūlymą leisti baltarusiams pateikti 3 naujus narius ${ }^{49}$. Tarybos sudettis baltarusių atstovais papildyta tik 1919 m. balandžio 4 d. - i LVT kooptuoti Gardino krašto atstovai, Upravos (žr. 19 išnašą) nariai: protojerëjus Ivanas Korčynskis ${ }^{50}$ ir medicinos daktaras Kanstantinas Bialeckis ${ }^{51}$. Pirmasis pasižymejjo nelabai gera moskalofilo ir juodosios šimtinès reputacija, bet laikui bėgant tapo baltarusių judejjimo šalininku ${ }^{52}$. Antrasis buvo baltarusių pulko Gardine gydytojas ir aktyvus kultūros veikejjas. Trečiuoju baltarusių atstovu tapo J. Voronko, kuris kartu tęsė ministro darbą Vyriausybejje ${ }^{53}$.

${ }^{48}$ D. Siamaška per pirmąji tarnybos Lietuvoje laikotarpi palaikè ryšius su A. Luckevičiumi. Pastarasis jo, kaip ir V. Lastauskio, buvimu Vakaruose planavo pasinaudoti įtraukiant Baltarusių Liaudies Respublikos delegaciją ị Paryžiaus konferenciją. $1919 \mathrm{~m}$. sausio $22 \mathrm{~d}$. BLR Liaudies ministrų rados liudijimas D. Siamaškai ir V. Lastauskiui. LCVA. F. 383, ap. 7, b. 39, lap. 116.

49 Lietuva. 1919, Nr. 12, p. 1.

${ }^{50}$ Ivanas Korčynskis (brus. Іван Корчынскі) (1865-1935) gimė Kijeve. 1885 m. Kijeve baigė stačiatikių kunigų seminariją, nuo 1900 m. gyveno Gardine, 1904 m. tapo Šv. Boriso ir Glebo vienuolyno protojerèjumi. İ baltarusių tautinị judèjimą ịsitraukè Pirmojo pasaulinio karo metu. Nuo $1919 \mathrm{~m}$. pradèjo ịvedinèti baltarusių kalbą pamaldose. Nuo $1920 \mathrm{~m}$. gyveno Kaune. 1923-1929 m. - Lietuvos stačiatikių vyskupijos tarybos pirmininkas, 1926-1935 m. - Lietuvos kariuomenès stačiatikių karo kapelionas. Mirè Alytuje.

${ }^{51}$ Kanstantinas Bialeckis (brus. Канстанцін Бялецкі) (1874-1926) gimé Lunoje. 1899 m. baigęs Peterburgo Karo medicinos akademiją, pradejo Gardino pèstininkų pulko gydytojo tarnybą. $1919 \mathrm{~m}$. tapo Baltarusių pèstininkų pulko gydytoju. $1920 \mathrm{~m}$. buvo aktyvus visuomenès veikejjas Gardine.

52 Чарнякевіч, А. Партрэт на фоне «інтэр“ера»: штодзённае жыццё беларускага дзеяча ў Гродна 1909-1939 г.г. Białoruś w XX stuleciu. W kręgu kultury i polityki. Toruń: Wydawnictwo Uniwersytetu Mikoaja Kopernika, 2007, p. 156.

53 Pranas Dovydaitis, 1919 m. kovo 12 d. tapęs Ministru Pirmininku, ipareigojo Baltarusių sekretoriatą pasiūlyti naują kandidatą i gudų reikalų ministro postą, iki to laiko pareigas eiti turejo J. Voronko. Vis dèlto kandidatūra nebuvo pristatyta, nors yra duomenų, kad buvo sumanymas pasiūlyti V. Lastauskio arba Petro Krečiauskio kandidatūras (Засецкі, М. Міністэрства беларускіх спрай: за 10 месяцаў істнаваньня, 1.ХІІ.1918 - 1.X.1919: кароткі нарыс. Коўна, 1919, р. 12-13). J. Voronko veikla šiame straipsnyje nėra išsamiai analizuojama. Nors oficialiai jis nuo 1919 m. balandžio mėn. iki 1920 m. gegužès mėn. buvo LVT narys, tuo pačiu metu ejjo ministro pareigas ir visa jo veikla buvo susijusi būtent su ministerija. 
Lenkų valdžia netrukus areštavo I. Korčynskị ir K. Bialeckį (kartu su kitais Baltarusių Gardino valdybos nariais). Nepaisant LVT protestų, jie buvo paleisti tik $1920 \mathrm{~m}$. pavasarị $i^{54}$. K. Bialeckis taip ir neatvyko $\mathfrak{i}$ Kauną, pasiliko Gardine, kur tęsè gydytojo praktiką. Jo politinės pažiūros tapo panašios ị Baltarusių tautinio komiteto, su kuriuo K. Bialeckis bendradarbiavo dar $1919 \mathrm{~m}$. Taip ir nepavyko nustatyti, ar po $1920 \mathrm{~m}$. jis apskritai turejjo ryšių su Lietuva. Vienintelis žinomas K. Bialeckio veiksmas, atliktas jam būnant sekretoriato nariu, buvo raštas Ministrui Pirmininkui Pranui Dovydaičiui, kuriame prašè ịtraukti Baltarusių sekretoriato atstovą $\mathfrak{i}$ Lietuvos ypatingosios misijos ị Varšuvą sudètį. I šią vietą K. Bialeckis siūlè V. Lastauskį, be to, jo siūlymu misijos sudètị turejjo papildyti vienas baltarusių karininkas, kurị nurodyti turètų sekretoriato atstovas.

Kaip minèta, D. Siamaška buvo Lietuvos delegacijos Paryžiuje nariu, nors ten, panašu, kaip ir LVT darbe Vilniuje ar Kaune, jo veikla nebuvo labai aktyvi. Jis nebuvo pasiruošęs tokio lygio užduotims ir nuo išvažiavimo ị Paryžių nepalaikė beveik jokių ryšių su baltarusiais. Jo pažiūros pamažu iggavo antibaltarusišką atspalvị, o jo vaidmuo Lietuvos delegacijoje tapo reikšmingas tik po BLR atstovo konferencijai A. Luckevičiaus atvykimo ị Paryžių 1919 m. vasarą. Galima teigti, kad D. Siamaška buvo pasinaudota BLR delegacijai neutralizuoti.

1919 m. birželio mèn. viduryje D. Siamaška parengè konferencijai „Memorandumą dèl baltarusių Lietuvos valstybèje “55, kuriame besąlygiškai pripažino Lietuvos valstybės teises (pagal 1918 m. lapkričio nutarimus) i Vilniaus ir Gardino kraštus. Toks žingsnis galèjo reikšti tik

541919 m. liepos 25 d. LVT protestas dèl Tarybos nario I. Korčynskio suèmimo. Езовитов, К. Белорусы и Поляки: документы и факты из истории оккупации Белоруссии поляками в 1918 и 1919 г2. Ковна: Издательство им. Ф. Скорыны, 1919, p. 82-83.

551919 m. birželio mėn. D. Siamaškos memorandumas Paryžiaus taikos konferencijai. Архівы Беларускай Народнай Рэспублікі. Дзяржаўнага Архіву Літвы (“Рада Міністраў Беларускай Народнай Рэспублікі”): фонд № 582. Вільня, 1998, т. 1, кн. 1, p. 352-353 (toliau - Apxiвы БНР). 
viena - visišką D. Siamaškos pašalinimą iš baltarusių judejjimo. D. Siamaškos pasirodymas Paryžiuje tapo dar viena sekretoriato konflikto su Vyriausybe priežastimi.

1919 m. birželio $18 \mathrm{~d}$. V. Lastauskis Baltarusių sekretoriato vardu iteikè premjerui raštą, kuriame pranešè: „Baltarusių atstovybė Lietuvos Valstybès Taryboje susipažinus su memorialu, kurị D. Siamaška ịteikè Paryžiaus Taikos konferencijai, praneša:

a) kad įteikto memorialo tekstas, prieš įteikiant Konferencijai nebuvo žinomas mūsų atstovybei, ir dèl to neišreiškia Baltarusių atstovybės, Lietuvos valstybès taryboje, balso;

b) savo memoriale ponas D. Siamaška leido sau rimtai performuoti sutarties punktus, pagal kuriuos, VBR pasiunté savo atstovus i Lietuvos Valstybès Tarybą;

Dèl to mes, Baltarusių atstovybė Lietuvos Valstybės Taryboje, prašome, pranešti p. D. Siamaškos žiniai, kad negalime jo laikyti savo atstovu Paryžiaus Taikos konferencijoje.

Šalia to primename $\langle\ldots\rangle$, kad pagal mūsų susitarimą Lietuvos delegacijoje Paryžiaus Taikos konferencijai turètų būti du baltarusių atstovai, ir laukiame paaiškinimų, kodèl ta sąlyga iki šiol nèra ivykdyta." 56

Negavęs atsakymo per 10 dienų, V. Lastauskis parengė kitą raštą, kuriame atsakè ị lietuvių pasiūlymą dalyvauti Komisijoje Steigiamojo Seimo rinkimų įstatymui rengti ${ }^{57}$. Atsižvelgdamas ị D. Siamaškos veiksmus ir negaudamas atsakymo ì minètą raštą, V. Lastauskis kritikavo Vyriausybės tylą ir protestavo dèl valstybès dokumentų spausdinimo tik lietuvių kalba. Taip pat minèjo baltarusiškos Lietuvos dalies santykių su lietuviškąja dalimi projekto atidejjimą, kuris

56 Dokumentas nèra datuotas, tačiau Siarhejus Šupa klysta nustatydamas jo datą liepos 2 d. - rašto kopija Ministrų kabineto raštinę pasiekè jau birželio 18 d. 1919 m. liepos $2 \mathrm{~d}$. Baltarusių atstovybès LVT raštas Lietuvos Respublikos Ministrui Pirmininkui. Apxiвы БНР. P. 373-374; LCVA. F. 923, ap. 1, b. 31, lap. 40.

571919 m. birželio 27 d. Baltarusių atstovybės LVT pranešimas Komisijai Steigiamojo Seimo rinkimų įstatymui rengti. Apхівы БНР. Р. 366. 
buvo įteiktas Prezidentui, Ministrui Pirmininkui ir LVT prezidiumui $^{58}$.

„Baltarusių atstovybė turi teisę manyti, kad Lietuvos vyriausybės veiksmai veda ị baltarusiškų žemių Lietuvos teritorijoje aneksavimą, o ne bendrą valstybès kūrimą - dèl to baltarusiai nusprendžia sustabdyti savo dalyvavimą komisijoje, iki to laiko, kol nebus atsakymo ị aukščiau minètus dokumentus ir apskritai nebus suformuoti mūsų teisiniai-valstybiniai santykiai“.

Tikètina, kad šie du raštai buvo savarankiškas V. Lastauskio žingsnis, nes tuo metu jis buvo vienintelis Baltarusių sekretoriato narys Kaune ir yra mažai tikimybès, kad šiuo klausimu jis konsultavosi su J. Voronko. Netrukus V. Lastauskis išvažiavo ị Vilnių. Nuo šio momento iki LVT veiklos pabaigos baltarusių darbai joje buvo šalutiniai. Tokią situaciją lèmé tai, kad Kaune nebuvo Baltarusių sekretoriato narių.

Sekretoriato vardu LVT oficialiai dalyvavo D. Siamaška, tačiau jis niekada nebuvo aktyvus posėďių dalyvis, todèl sunku nustatyti jo vaidmeni Taryboje. Pavyzdžiui, yra žinomas 1920 m. kovo 20 d. D. Siamaškos skaityto pranešimo tekstas Didžiosios ir Mažosios Lietuvos susijungimo proga: „Sveikindamas lietuvių tautos susijungimą, aš, kaipo Gudų atstovas, pabrěžiu, kad šitas istorinis faktas turi ir Gudų tautai tos pačios didelès reikšmès. Lietuvių žemėms susijungus vakaruose, prasidès lietuvių žemių susijungimas rytuose. Mes gerai atmename, kad nèr Lietuvos be Vilniaus, kad niekas negalès iš jos sienų išbraukti Gardino, Balstogès ir Bieloviežos, kad jokis kraujo ir geležies grasinimas neprivers mus užmiršti apie Vilniaus ir Gardino žemių sūnus. Ir dabar, kai mes pasiekèm laisvų Baltijos bangų, imsime siekti žalių Gudų žemės girių. ${ }^{\text {"59 }}$

${ }^{58}$ Greičiausiai V. Lastauskis omenyje turi projektą „Dèl baltarusiškosios Lietuvos dalies valdymo“, dokumentą, kuris buvo parengtas 1919 m. pradžioje ir pristatytas Lietuvos valdžiai, nors niekada išsamiai nebuvo nagrinèjamas. Žr. Блашчак, T. Міністэрства беларускіх справаў ураду Літоўскай Рэспублікі (1918-1924). ARCHЕ-Пачатак. 2010, № 1-2, p. 238-239; Liekis, Š. Rytų Lietuva ir Baltarusija 1915-1923. Lietuvos sienu raida. Vilnius, 1997, t. 2, p. 366.

${ }^{59}$ Liekis, A. Lietuviu tautos prisikelimas: šviesuoliai inteligentai lietuviu tautos istorijoje (iki 1920 m.). Vilnius: Mokslotyros institutas, 2006, p. 793. 
Paskutinis D. Siamaškos, kaip LVT nario, žingsnis buvo dalyvavimas Lietuvių delegacijoje taikos deryboms su Sovietų Rusija. Reikètų atkreipti dėmesí, kad D. Siamaška ị Maskvą išvažiavo ne kaip Lietuvos baltarusių atstovas, o kaip LVT narys ${ }^{60}$. Kita vertus, sovietai kaip vienintelę baltarusių tautos atstovybę pripažino tik Baltarusių Tarybų Socialistinę Respubliką, kurią tuo metu buvo užèmusi Lenkijos kariuomenè. Pakeliui ị Maskvą D. Siamaška Rygoje susitiko su V. Lastauskiu, kuris tuo metu (nuo 1919 m. gruodžio mèn.) ejjo BLR Ministro Pirmininko pareigas. V. Lastauskis pasiūlè Lietuvai kartu veikti prieš Lenkiją ir Rusiją ir buvo pasiruošęs atsisakyti „labiausiai ginčytinų paribio teritorijų“ už BLR pripažinimą ${ }^{61}$. Toks pasiūlymas liko be atsako, o prieš D. Siamaškos dalyvavimą Lietuvos delegacijoje protestavo Vilniaus ir Gardino kraštų baltarusių rada (ikurta 1919 m. birželio mèn.). D. Siamaška, kaip delegacijos narys, atliko minimalų vaidmeni ir greitai buvo išsiųstas ị Kauną konsultuotis.

Baltarusių sekretoriatas, kaip baltarusių atstovybė LVT, oficialiai nustojo egzistuoti likvidavus LVT ir perdavus jos kompetenciją Steigiamajam Seimui. Rinkimai ị Seimą pagal 1919 m. lapkričio $20 \mathrm{~d}$. Rinkimų ịstatymą turejo vykti visose teritorijose, ị kurias pretendavo Lietuvos valstybè, bet $1920 \mathrm{~m}$. balandžio 14-15 dienomis jie surengti tik tose žemèse, kurias kontroliavo lietuviai. Baltarusiai, kaip minèta, atsisakè dalyvauti rinkimų komisijoje ir nepateikè savo sąrašo rinkimuose. Taip nustojo galioti vienas iš 1918 m. lapkričio mèn. susitarimų punktų, kuriame baltarusių atstovybe ịvardyta Lietuvos ịstatymų leidžiamojo organo dalimi.

${ }^{60} 1920$ m. balandžio 29 d. igaliojimas D. Siamaškai. LCVA. F. 383, ap. 3, b. 27, lap. 86 .

${ }^{61} 1920$ m. balandžio 17 d. BLR Ministro Pirmininko V. Lastauskio raštas Lietuvos užsienio reikalų ministerijai. Архівы БНР. P. 720. 


\section{Išvados}

1. Mažumų klausimas Lietuvos Taryboje buvo itin svarbus kuriant Lietuvos valstybingumą. Vokiečių administracija darè nuolatinị spaudimą Tarybai, kad ši ị savo sudėtị įtrauktų visų Lietuvos tautų atstovus. Kadangi lenkai ir žydai nebuvo suinteresuoti bendradarbiauti, vieninteliu partneriu galejo tapti tik baltarusiai.

2. Baltarusių ịjjimas ị Lietuvos Valstybès Tarybą buvo didelis Tarybos laimejjimas. LVT, beveik nieko nepažadejjusi baltarusiams, sustiprino savo poziciją tarptautinès politikos arenoje.

3. Tiek lietuvių, tiek baltarusių požiūris i $1918 \mathrm{~m}$. lapkričio mèn. susitarimus skyrèsi, o tai, kad neivyko tikros derybos ir nebuvo sudaryta sutartis, leido abiem pusėms laisvai interpretuoti susitarimų sąlygas, kaltinti dèl neįvykdytų pažadų.

4. Dèl greito pasitraukimo iš Vilniaus, o vèliau baltarusių etninių žemių praradimo, baltarusių klausimas Lietuvos valstybeje liko tik teorinis, bet turejjo nemažai reikšmès priimant sprendimą dèl Lietuvos rytinių sienų, kovojant dèl Vilniaus ir igyvendinant tarptautinę politiką.

5. 1918 m. rudeni sudarius Vyriausybę, Tarybos vaidmuo Lietuvos politikoje buvo laipsniškai marginalizuojamas. Jos nariai ịsitrauke i veiklą kitose valstybès institucijose ir negalèjo nuolat dalyvauti posėdžiuose. Taip pat buvo ir su baltarusiais. O kadangi po $1918 \mathrm{~m}$. gruodžio mèn. Tarybos pasitraukimo iš Vilniaus ị Kauną dauguma baltarusių pasitraukè iš Tarybos darbų, realus sprendimas dèl baltarusių padèties buvo paliktas Lietuvai. 


\title{
BELARUSIANS IN LITHUANIAN STATE COUNCIL (1918-1920)
}

\author{
Tomasz BŁAszczAK
}

\section{Summary}

Keywords: Council of Lithuania; Vilnius Belarusian Rada; Belarusian Secretary; ethnic minorities in Lithuania.

This article shows and analyses Belarusian question in the works of Lithuanian State Council, starting from the very first days of it's establishment in the fall of 1917, till the end of it's works in the spring of 1920. The main object of research - the Belarusian representation in the Lithuanian State Council (sometimes called Belarusian Secretary or Belarusian fraction), which existed from the 27th of November 1918. Analyse is based on the archival materials, stored in various Lithuanian and Belarusian archives, printed sources, as well Belarusian and Lithuanian press. The first question considered are the circumstances and conditions' of Belarusian's entry into the Council, formation of their representation in the Council, and it's work during the last weeks of 1918. The case of Lithu-
anian-Belarusian collaboration during the period of early Lithuanian state-bulilding had changed after evacuation of Council and Government to Kaunas during the first days of 1919. Having less impact on the Belarusian ethnic territories, Lithuanian side started to regard Belarusian question more as a factor of foreign policy than it's interior affairs. However it was not working actively, Belarusian fraction in the Council still existed, changed its composition in the April of 1919, and together with Ministry of Belarusian Affairs constructed legal representation of Belarusian minority in the country. The author paid attention to the works of representation, positions of it's members and their political views on the development of Belarusian-Lithuanian relations.

Iteikta 2013 m. lapkričio 19 d. 